\title{
Deceased organ donation potential in Canada: a review of consecutive deaths in Alberta
}

\section{Potentiel des dons d'organes après décès au Canada : un compte rendu de décès consécutifs en Alberta}

\author{
Andreas H. Kramer, MD, MSc, FRCPC (1) - Karen Hornby, BSCN, MSc • \\ Christopher J. Doig, MD, MSc • Denise Armstrong, PhD • Laura Grantham • \\ Sherri Kashuba, MHSA • Philippe L. Couillard, MD • \\ Demetrios J. Kutsogiannis, MD, MSc
}

Received: 17 January 2019/Revised: 22 April 2019/Accepted: 30 April 2019/Published online: 25 June 2019

(C) Canadian Anesthesiologists' Society 2019

\begin{abstract}
Background Transplantation is the most effective treatment for many patients with end-stage organ failure. There is a gap between the number of patients who would benefit from transplantation and availability of organs. We assessed maximum potential for deceased donation in Alberta and barriers to increasing the donation rate.
\end{abstract}

Electronic supplementary material The online version of this article (https://doi.org/10.1007/s12630-019-01437-1) contains supplementary material, which is available to authorized users.

A. H. Kramer, MD, MSc, FRCPC ( $\varangle)$ · P. L. Couillard, MD Departments of Critical Care Medicine \& Clinical Neurosciences, University of Calgary, 3132 Hospital Drive NW, Calgary, AB, Canada

e-mail: Andreas.Kramer@AlbertaHealthServices.ca

K. Hornby, BSCN, MSc

Research Support Services Program, Trillium Gift of Life

Network, Toronto, ON, Canada

C. J. Doig, MD, MSc

Departments of Critical Care Medicine \& Community Health

Sciences, University of Calgary, Calgary, AB, Canada

D. Armstrong, $\mathrm{PhD} \cdot \mathrm{L}$. Grantham

Alberta Organ \& Tissue Donation Program, Calgary, AB,

Canada

S. Kashuba, MHSA

Critical Care Strategic Clinical Network, Alberta Health

Services, Edmonton, AB, Canada

D. J. Kutsogiannis, MD, MSc

Department of Critical Care Medicine, University of Alberta,

Edmonton, AB, Canada
Methods All deaths that occurred in Alberta in 2015 in areas where mechanical ventilation could be provided were retrospectively identified using administrative data. Medical records were reviewed by donation coordinators and critical care physicians with expertise in donation, using a standardized tool to determine whether deceased patients could potentially have been organ donors.

Results There were 2,706 deaths occurring in either an intensive care unit or emergency department, of which 1,252 were attributable to a non-neurologic cause: 946 involved cardiac arrests with unsuccessful resuscitation, and 57 were not mechanically ventilated. Of the remaining 451 deaths, 117 (28 donors per million population [dpmp]) either were, or could potentially have been, organ donors after neurologic determination of death (NDD). Of these, 19 (4.5 dpmp) were not appropriately identified or referred, and 45 approached families (10.8 dpmp) did not provide consent. Non-identified NDD cases accounted for a larger proportion of deaths due to neurologic causes in emergency departments (18\%) than in intensive care units $(2 \%)(P<0.0001)$ and in rural $(9 \%)$ compared with urban centres (3\%) $(P=0.05)$. If routinely available, donation after circulatory death (DCD) could potentially have been possible in as many as 113 (27 dpmp) cases.

Conclusions Maximum deceased organ donation potential in Alberta is approximately 55 dpmp. The current donation rate has potential to increase with more widespread availability of DCD and a higher consent rate.

Résumé

Contexte La transplantation est le traitement le plus efficace pour de nombreux patients atteints de défaillance viscérale terminale. Il existe un fossé entre le nombre de 
patients qui bénéficieraient d'une transplantation et la disponibilité d'organes. Nous avons évalué le potentiel maximal de dons d'organes après décès en Alberta et les obstacles à une augmentation du taux de dons.

Méthode À l'aide des données administratives, nous avons identifié de façon rétrospective tous les décès survenus en Alberta en 2015 dans les endroits où une ventilation mécanique pouvait être offerte. Les dossiers médicaux ont été passés en revue à l'aide d'un outil standardisé par des coordonnateurs de dons et des médecins des soins critiques possédant une expertise en matière de dons d'organes afin de déterminer si les patients décédés auraient pu être des donneurs potentiels d'organes.

Résultats $A u$ total, 2706 décès sont survenus, soit dans une unité de soins intensifs ou dans un département d'urgence, dont 1252 étaient attribuables à une cause non neurologique; 946 décès sont survenus à la suite d'arrêts cardiaques avec échec de réanimation, et 57 n'ont pas bénéficié de ventilation mécanique. Parmi les 451 décès restants, 117 (28 donneurs par million d'habitants [dpmh]) étaient, ou auraient pu être, des donneurs d'organes après détermination $d u$ décès neurologique (DDN). Parmi ces derniers, 19 (4,5 dpmh) n'étaient pas adéquatement identifiés ou référés, et 45 familles (10,8 dpmh) approchées n'ont pas donné leur consentement. Les cas de DDN non identifiés expliquaient une plus grande proportion des décès pour causes neurologiques dans les départements d'urgence (18\%) que dans les unités de soins intensifs $(2 \%)(P<0,0001)$, et dans les communautés rurales (9\%) par rapport aux centres urbains $(3 \%)(P=0,05)$. Si disponibles, les dons après décès cardiocirculatoire (DDC) auraient pu être possibles dans 113 cas (27 dpmh).

Conclusion Le potentiel maximal de dons d'organes après décès en Alberta est d'environ 55 dpmh. Le taux actuel de dons pourrait augmenter si la DDC était plus disponible et que le taux de consentement était plus élevé.

Organ transplantation improves survival and quality of life, and reduces societal costs in many patients with end-stage organ failure. ${ }^{1-8}$ There remains a large gap between the number of patients who would benefit from transplantation and the availability of organs in Canada, with over 4,000 Canadians on waitlists, of which 200-300 die each year without receiving a transplant. 9,10

Although the national deceased organ donation rate has increased and now exceeds 20 donors per million population, it remains well below that of some countries. $^{9-11}$ This observation is thought to be due, in part, to barriers in the identification and referral of potential donors. Nevertheless, epidemiologic studies suggest that geographic differences in demographics and rates of brain injury may account for some variability in donation rates. $^{12,13}$ For example, in Canada there has been a reduction over time in the incidence of severe traumatic brain injury, particularly in younger people, as well as in the proportion of critically ill, brain-injured patients that progress to neurologic determination of death (NDD). ${ }^{14-16}$ Donation after circulatory determination of death (DCD) is steadily increasing but is not yet universally available across Canada.

There have been previous attempts to estimate donation potential in Canada. A study from the Canadian Institute of Health Information (CIHI) utilized administrative data and concluded that there may be as many as 89-107 potential organ donors per million population. ${ }^{17}$ Nevertheless, administrative data cannot reliably identify all factors that may prevent patients from becoming organ donors, such as the time interval between withdrawal of lifesustaining treatments and death (donation is generally not possible if this is more than one to two hours), prohibitive organ dysfunction (whereby grafts may not function in recipients), and unsupportable physiology (which precludes the necessary workup to prepare for donation). Consequently, administrative data overestimates donation potential. $^{18}$

Regular medical record reviews have been recommended as an important component of a highquality donation system, since they may identify missed opportunities, and in turn promote quality improvement. ${ }^{9}$ We performed a population-based medical record review of all deaths occurring in the province of Alberta in 2015 in areas capable of providing mechanical ventilation. Our objectives were to determine provincial donation potential, assess where in our healthcare system opportunities for improvement may exist, and evaluate the accuracy of administrative data in estimating donation potential.

\section{Methods}

This project was carried out in partnership between Alberta Health Services and the provincial health ministry. Based on criteria set out by the Alberta Research Ethics Community Consensus Initiative and verified on the Conjoint Health Research Ethics Board website, this work met criteria for a quality improvement initiative that did not require formal review by a Research Ethics Board. ${ }^{19}$ Data collection was supported by a grant from Alberta Health.

Deaths occurring in Alberta hospitals in 2015 were identified using two national administrative databases: Discharge Abstract Database (DAD) and National 
Ambulatory Care Reporting Service (NACRS). The search was restricted to patients that died in a special care unit that was capable of providing invasive mechanical ventilation (emergency department or intensive care unit [ICU]).

All other data were extracted manually from medical records using a death audit tool that was developed in collaboration with Canadian Blood Services (CBS; eAppendix 1, available as Electronic Supplementary Material [ESM]). Apart from paper-based medical records, reviewers had access to an electronic clinical information system that documents minute-by-minute vital signs and an electronic medical record, both of which are used across the entire province of Alberta (Metavision, iMD soft, Israel and Alberta NetCare, respectively). Metavision also includes an admission diagnosis for every ICU patient, as well as the cause of death when there is ICU mortality, both of which are prospectively assigned by the attending critical care physician.

Medical records were initially reviewed by a donation coordinator. Based on all available documentation, deaths were categorized as having been due to one of the following: non-neurologic cause; cardiac arrest from which a patient could not be resuscitated; or neurologic cause. Deaths from neurologic causes were, in turn, classified as follows: hypoxic-ischemic brain injury (HIBI), traumatic brain injury (TBI), subarachnoid hemorrhage $(\mathrm{SAH})$, intracerebral hemorrhage (ICH), ischemic stroke, or less common conditions that were clustered together under the heading "other" (e.g., central nervous system infections and brain tumours). Subdural hematomas that occurred spontaneously or with only minor trauma were combined with TBI. Cause of death was verified by a physician reviewer.

Patients that died because of non-neurologic causes were excluded because they do not have a pathophysiologic process that leads to NDD and are rarely eligible for DCD (e.g., $>95 \%$ of DCD donors in Ontario have had a neurologic cause of death and in some Canadian regions only patients with neurologic concerns are currently considered eligible). ${ }^{20}$ This approach is consistent with other literature and recommendations of a CBS committee for monitoring deceased donation performance in Canada. ${ }^{17,18,21}$ Patients that could not be resuscitated from a cardiac arrest were excluded because uncontrolled DCD (the practice of placing "deceased" patients that cannot be resuscitated from a cardiac arrest on extracorporeal life-support solely for the purpose of perfusing and procuring their organs) is currently not performed in Canada. In addition, medical record review was stopped if there was no mechanical ventilation in the final $24 \mathrm{hr}$ prior to death, since this scenario is inconsistent with the option of controlled DCD.
Remaining deaths were reviewed by both a donation coordinator and a neurocritical care and organ donation specialist (eAppendix 2, available as ESM). Patients were categorized as potential missed NDD donors if all of the following criteria were met: 1) the last documented neurologic examination showed no eye opening or motor response to noxious stimulation; 2) all documented brainstem reflexes including respiration were absent; 3) there was no documentation in the medical record that the possibility of neurologic death had been considered and the family had, in turn, been approached regarding donation; and 4) there was no overt contraindication to donation (e.g., hematologic malignancy, active metastatic cancer, HIV, active tuberculosis, or West Nile virus).

Patients were considered to be potential DCD donors if: 1) they were less than $70 \mathrm{yr}$ old (older patients can be NDD, but not DCD donors in most parts of Canada); 2) the last documented examination was inconsistent with neurologic death based on preservation of a motor response to noxious stimulation or presence of brainstem reflexes; 3) death occurred within two hours of withdrawal of life-sustaining treatments; and 4) there was no overt contraindication to donation.

Cases where there was a discrepancy between the two reviewers regarding eligibility for organ donation were reviewed by a second critical care physician with expertise in neurocritical care and organ donation, with further disagreements resolved by discussion and (if necessary) involvement of a third critical care physician with similar expertise. Skill and knowledge in the management of critically ill patients with severe brain injury and close familiarity with diagnostic criteria for "brain death" are mandatory requirements in NDD according to Canadian guidelines. $^{22}$ For this reason, consensus among physician reviewers was considered the reference standard. The population of Alberta in 2015 (4.18 million) was obtained from Statistics Canada for the purpose of calculating donors per million population.

We also utilized the same methodology described previously by $\mathrm{CIHI}$ and Rose et al. to estimate the number of potential deceased donors using only Alberta administrative data (DAD and NACRS) for 2015 (eAppendix 3, available as ESM) and compared this value against our determination of donation potential using full medical record review. ${ }^{17,18}$

Statistical analysis was completed using SAS version 9.3 (Cary, NC, USA). Continuous data are presented as median [interquartile range] and categorical data are presented as proportions. Kappa scores were used to assess inter-observer agreement in determination of donation potential. Sensitivity and specificity of potential donor identification by donation coordinators were calculated in the standard fashion [(true positives - false 
negatives)/true positives and (true negatives - false positives)/true negatives, respectively].

\section{Results}

There were 2,706 deaths in areas of Alberta hospitals where sustained mechanical ventilation could be provided. Of these deaths, $1,252(46 \%)$ were attributable to a nonneurologic cause; $946(35 \%)$ were due to cardiac arrests where patients could not be resuscitated, and 57 (2\%) involved patients that died because of a neurologic condition, but were not mechanically ventilated within 24 hr of death (Figure).

Of the remaining 451 patients (Table 1), 408 (90\%) died in either Edmonton or Calgary, although only 213 (47\%) had urban postal codes. Patients that died in non-urban hospitals did not differ significantly from those in urban hospitals in distribution of age (55 [41-69] vs 56 [38-67] yr, $P=0.50)$ or sex (47\% vs $37 \%$ female, $P=0.23)$, but HIBI was the cause of death in a larger proportion of patients (63\% vs $47 \%, P=0.05$ ).

The majority of deaths $(411,91 \%)$ occurred in an ICU setting, with only 40 (9\%) in an emergency department. Patients that died in the emergency department did not differ significantly from those in an ICU in relation to distribution of sex (35\% vs $38 \%$ female, $P=0.67)$, but were older (65 [54-76] vs 55 [36-67] yr, $P=0.0007)$ and more likely to have died of a form of stroke (ischemic stroke, $\mathrm{ICH}$, or $\mathrm{SAH})(48 \%$ vs $25 \%, P=0.002)$. Pediatric patients $(<18 \mathrm{yr})$ accounted for $29(6 \%)$ of deaths. The most common cause of death was HIBI (48\%), followed by TBI (20\%), ICH (12\%), ischemic stroke (10\%), and SAH $(6 \%)$.

One hundred and twenty-two of the 451 patients (27\%) either had confirmed NDD or were suspected of having met NDD criteria, given that they had no motor response to noxious stimulation and absence of all recorded brainstem reflexes, but without completion of all necessary confirmatory testing (including an apnea test or demonstration of absent cerebral blood flow). Of these, five had overt contraindications to organ donation and one had non-viable organs, such that overall NDD donation potential in 2015 was 28 donors per million population.

The approach rate for the families of eligible NDD patients was $91 / 114$ (80\%; excluded from the denominator are those with contraindications, medical examiner refusal, or no surrogate decision maker). Reasons for non-approach included erroneous beliefs about ineligibility for donation (2) and concerns about family dynamics (4), but in 17 cases (15\%) no clear reason was documented. In these 17 cases, medical records revealed lack of any motor response and absence of pupillary light reflexes in all cases. All cases also had documented absence of at least one additional brainstem reflex or absence of respiration. Nevertheless, healthcare professionals' documentation of other brainstem reflexes in the medical record was inconsistent (absence of corneal, oculocephalic, cough, and gag reflexes in 11/17 [65\%], 3/17 [18\%], 2/17 [12\%], and 7/17 [41\%], respectively, and absence of respiratory effort in 13/17 [76\%]).

Of the 40 deaths attributable to a neurologic cause occurring in an emergency department, seven (18\%) were possible missed NDD cases compared with 10/411 (2\%) deaths in an ICU $(P<0.0001)$. Similarly, of 43 deaths occurring outside urban centres, four $(9 \%)$ were missed NDD cases compared with 13/408 (3\%) deaths in Edmonton or Calgary $(P=0.05)$. Consent was obtained in 46/91 (51\%) approached potential NDD donors, of which 43 donated an average of 4.1 organs (lungs counted as one organ). Families were initially approached by the critical care team and formal consent was subsequently obtained by donation coordinators.

Of the remaining 329 patients, 167 (38\%) were potential DCD donors, but only 113 died within two hours of withdrawal of life-sustaining treatments, for an overall DCD potential of 27 per million population. Other reasons for ineligibility included age $\geq 70 \mathrm{yr}$ (71), various contraindications to organ donation (48), and profound physiologic instability (30). DCD was only availalbe in one Alberta ICU in 2015, such that only a small number of families were approached, of which six donated organs (mean of 3.5 per donor). Combining potential NDD and DCD donors, the overall maximum organ donation potential was 55 donors per million population.

Among potential DCD donors, documentation of brainstem reflexes ranged from a minimum of 68/329 (21\%) for oculocephalic reflexes to a maximum of $272 / 329$ (83\%) for pupillary light reflexes. Nevertheless, there was at least some definitive evidence in all cases that criteria for NDD would not have been met at the time of withdrawal of mechanical ventilation. Of the 167 potential DCD donors younger than $70 \mathrm{yr}$ of age, 155 had computed tomography or magnetic resonance imaging scan results available prior to death, of which 61 (39\%) showed at least partial effacement of basal cisterns or at least $1 \mathrm{~cm}$ of midline shift at the level of the septum pellucidum.

Among the 451 patients that died of a neurologic cause and had received mechanical ventilation prior to death, agreement between initial donation coordinator review and final adjudication regarding eligibility for organ donation occurred in $84 \%$ of cases, with a kappa statistic of 0.67 (0.60-0.73). Sensitivity of the first donor coordinator screen was 94\% (90-97\%) and specificity 71\% (65-77\%). Agreement between physicians in cases of discrepancy 


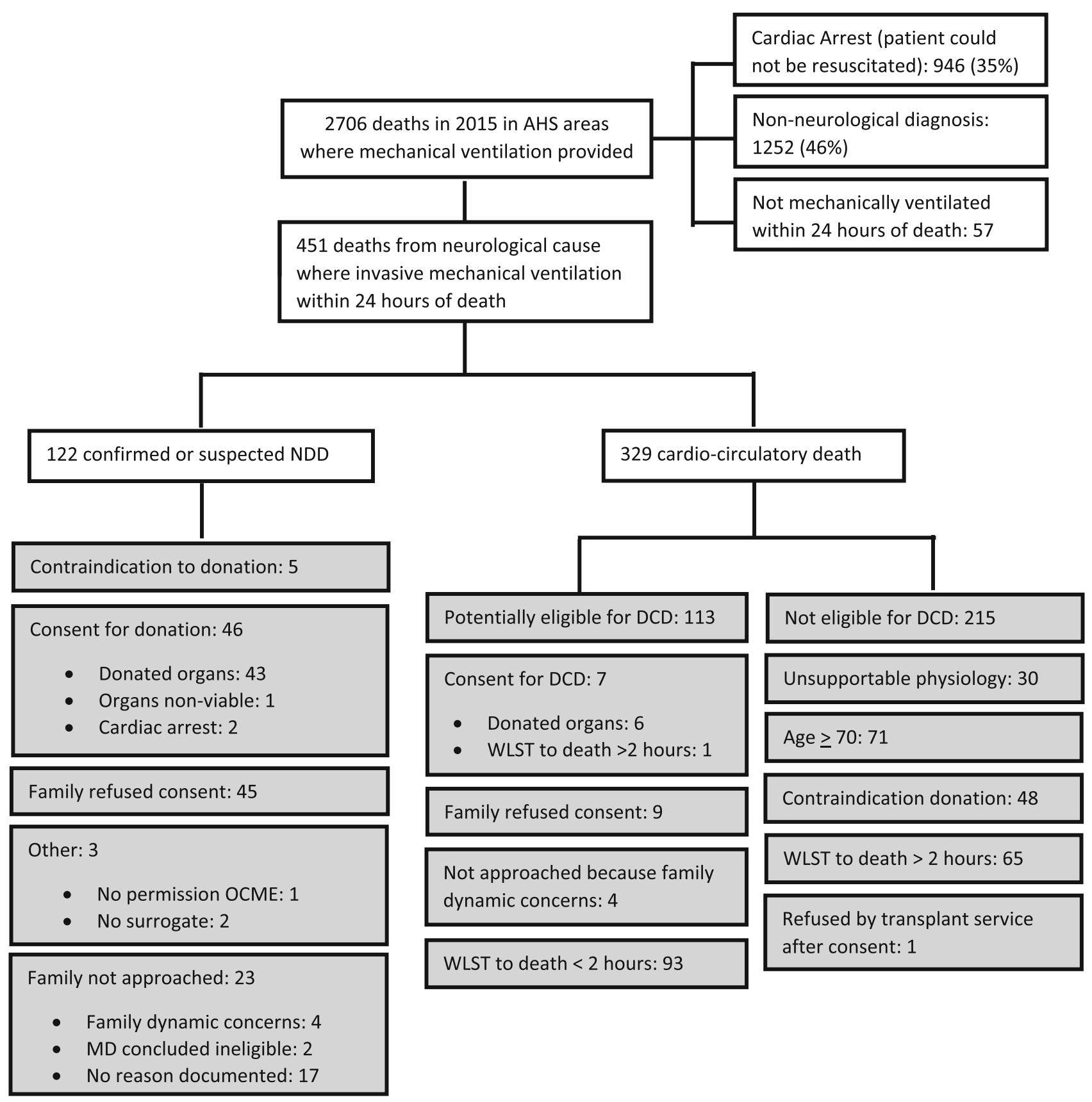

Abbreviations: AHS = Alberta Health Services; $D C D=$ donation after cardio-circulatory death; NDD = neurological determination of death; OCME = Office of the Chief Medical Examiner; WLST $=$ withdrawal of lifesustaining treatments

* Missing data 1 patient

Figure Flow chart describing hospital deaths in Alberta, Canada in 2015

during initial review occurred in $95 \%$ of cases, with a kappa statistic of $0.82(0.64-0.99)$.
Administrative data from 2015 suggested that there could be as many as 623 potential organ donors in Alberta (eAppendix 3, available as ESM). Compared with our 
Table 1 Characteristics of potential organ donors in Alberta, Canada in 2015

\begin{tabular}{|c|c|c|c|}
\hline & NDD $(n=117)$ & $\operatorname{DCD}(n=113)$ & Not eligible for organ donation $(n=221)$ \\
\hline Age & $45(29-59)$ & $49(34-60)$ & $64(49-73)$ \\
\hline \multicolumn{4}{|l|}{ Sex } \\
\hline Male & $77(66 \%)$ & $67(59 \%)$ & $135(61 \%)$ \\
\hline Female & $40(34 \%)$ & $46(41 \%)$ & $86(39 \%)$ \\
\hline \multicolumn{4}{|l|}{ Postal code } \\
\hline Edmonton & $25(21 \%)$ & $24(21 \%)$ & $54(24 \%)$ \\
\hline Calgary & $33(28 \%)$ & $31(27 \%)$ & $46(21 \%)$ \\
\hline Other & $53(45 \%)$ & $51(45 \%)$ & $101(46 \%)$ \\
\hline None available & $6(5 \%)$ & $7(6 \%)$ & $20(9 \%)$ \\
\hline \multicolumn{4}{|l|}{ City (where patient died) } \\
\hline Edmonton & $56(48 \%)$ & $44(39 \%)$ & $109(49 \%)$ \\
\hline Calgary & $50(43 \%)$ & $55(49 \%)$ & $94(43 \%)$ \\
\hline Rural & $11(9 \%)$ & $14(12 \%)$ & $18(8 \%)$ \\
\hline \multicolumn{4}{|l|}{ Diagnosis } \\
\hline HIBI & $56(48 \%)$ & $56(49 \%)$ & $107(48 \%)$ \\
\hline TBI & $29(25 \%)$ & $23(20 \%)$ & $37(17 \%)$ \\
\hline $\mathrm{ICH}$ & $12(10 \%)$ & $15(13 \%)$ & $25(11 \%)$ \\
\hline SAH & $10(8 \%)$ & $5(4 \%)$ & $10(5 \%)$ \\
\hline IS & $4(3 \%)$ & $13(12 \%)$ & $27(12 \%)$ \\
\hline Other & $6(5 \%)$ & $1(1 \%)$ & $15(7 \%)$ \\
\hline \multicolumn{4}{|l|}{ Setting } \\
\hline Multi-system adult ICU & $90(77 \%)$ & $85(75 \%)$ & $148(67 \%)$ \\
\hline Cardiac ICU & $8(7 \%)$ & $11(10 \%)$ & $38(17 \%)$ \\
\hline Emergency department & $13(11 \%)$ & $6(5 \%)$ & $21(10 \%)$ \\
\hline Pediatric ICU & $6(5 \%)$ & $11(10 \%)$ & $12(5 \%)$ \\
\hline Other & 0 & 0 & $2(1 \%)$ \\
\hline
\end{tabular}

DCD = donation after cardiocirculatory determination of death; HIBI = hypoxic-ischemic brain injury; ICH = intracerebral hemorrhage; ICU = intensive care unit; IS = ischemic stroke; NDD = neurologic determination of death; $\mathrm{SAH}=$ subarachnoid hemorrhage; $\mathrm{TBI}=$ traumatic brain injury

Table 2 Comparison of number of potential organ donors using administrative data (Discharge Abstract Database and National Ambulatory Care Reporting System) and medical record review according to age group

\begin{tabular}{lcll}
\hline & $\begin{array}{l}\text { Administrative } \\
\text { data }\end{array}$ & $\begin{array}{l}\text { Medical record } \\
\text { review }\end{array}$ & $\begin{array}{l}\text { Overestimate } \\
\text { ratio }\end{array}$ \\
\hline$<20 \mathrm{yr}$ & 64 & 26 & 2.5 \\
$20-49$ & 205 & 96 & 2.1 \\
$50-59$ & 155 & 52 & 3.0 \\
$60-69$ & 199 & 45 & 4.4 \\
Overall* & 623 & 219 & 2.8
\end{tabular}

*This excludes patients $\geq 70 \mathrm{yr}$ of age who became organ donors following neurologic determination of death

detailed medical record review, administrative data overestimated donation potential 2.8 -fold. The degree of overestimation was higher in older age groups (e.g., 4.4- fold in deaths among patients 60-69 yr of age $v s$ 2.1-fold in deaths among patients 20-49 yr of age) (Table 2).

\section{Discussion}

In this one-year review of deaths occurring in the province of Alberta, we estimated the maximum organ donation potential to be 55 donors per million population. Unlike previous assessments of donation potential, this determination was made with all medical records reviewed by at least two experts, including both a nurse donation coordinator and a physician with expertise in organ donation and the care of critically ill brain-injured patients. Our estimate of donation potential is substantially lower than that reported by CIHI because, unlike medical record reviews, administrative data do not account for numerous factors that may prevent patients that die due to 
devastating brain injuries from becoming organ donors. $^{17,18}$

Our findings show opportunities for quality improvement. There were occasional cases of NDD that were not recognized by front-line healthcare professionals or were erroneously considered ineligible for donation and therefore not referred to an organ donation agency. A disproportionally large number of such cases occurred in emergency departments and outside urban centres. Because patients with severe brain injury that progress to NDD are most often cared for in urban ICUs, healthcare professionals in rural settings or emergency departments may be less familiar with criteria for NDD. Although our findings suggest a role for increased education, they also indicate that missed cases of NDD are perhaps less common than they once were. ${ }^{23}$

From the perspective of patients' families, dealing with death due to devastating brain injury is usually emotionally overwhelming. Although survey data suggest that the vast majority of Canadians are favorably disposed towards deceased organ donation, lack of surrogate consent was the most common reason why patients that had progressed to NDD did not become organ donors. ${ }^{24}$ The consent rate we observed is consistent with other recent Canadian data. ${ }^{25}$ This suggests that there may be opportunities to increase organ donation through further public education, promotion of donation registries, and education for healthcare providers that conduct conversations with families regarding donation. ${ }^{26}$ Further research is necessary to better understand reasons for non-consent.

The most common reason for death in patients with catastrophic brain injury and a dismal prognosis is not progression to NDD but circulatory arrest following withdrawal of life-sustaining therapies. Our findings show that the greatest potential for increased deceased organ donation is through DCD rather than donation after NDD. Donation after circulatory determination of death has been practiced in Canada since 2006 and has been gradually increasing in volume. Although a national guideline document has been published, ${ }^{27}$ aspects of DCD have remained controversial, such as criteria used to define death, ${ }^{28}$ the need for certain premortem interventions, ${ }^{29}$ and inconsistencies in neuro-prognostication (with more pessimistic approaches and earlier withdrawal of lifesustaining treatments potentially leading to more frequent consideration of DCD). ${ }^{30}$ Despite these concerns, most clinicians believe that appropriate safeguards can be incorporated into well-developed DCD policies and procedures to protect patients, maintain public trust, and maximize donation opportunities. ${ }^{31}$

Although pediatric patients account for only a small proportion of potential organ donors, appropriate identification and referral is particularly important for children in need of a transplant, in whom larger organs from adults may be unsuitable. Our findings show that more widespread availability of pediatric DCD could have a moderate impact on the number of pediatric organ donors. $^{32}$

CBS has recommended that audits of deaths occurring in ICUs and emergency departments should be performed prospectively for quality assurance and improvement in the identification and referral of potential organ donors. ${ }^{9,10} \mathrm{We}$ found reviews conducted by donation coordinators to have a high sensitivity, but only moderate specificity. As such, we believe these reviews should be conducted with the involvement of experts in critical care and organ donation, with explicit criteria for defining deceased patients as potential organ donors. Our findings suggest that administrative data can perhaps be used as a means of screening deaths for more detailed review (especially among younger patients where the false positive rate is lower), but substantially overestimate donation potential and should therefore not be used as a stand-alone measure.

With about 28 potential NDD donors per million population, our findings show that donation rates observed in some countries are currently not achievable in Canada. Spain has the highest donation rate in the world, recently exceeding 40 donors per million population, of which more than $80 \%$ were donors after NDD. ${ }^{11}$ As acknowledged by Matesanz et al., an important factor in this high rate has been an explicit policy of deliberate initiation or continuation of "elective non-therapeutic ventilation" in patients, most often elderly, with no realistic hope of a favourable outcome, specifically for the purpose of awaiting possible progression to NDD and organ donation. It has been estimated that almost a quarter of organ donors in Spain are admitted to an ICU solely to facilitate donation. ${ }^{11,33}$ In Canada, the incidence and duration of non-therapeutic ventilation is unknown, but is thought to be relatively uncommon and brief, since treatment of patients with no realistic hope of a favourable outcome is usually aimed primarily at maximizing comfort. ${ }^{34}$ It is likely that a proportion of potential DCD donors in our cohort would have progressed to NDD if mechanical ventilation had been provided for longer. Supporting this notion, 39\% of potential DCD donors had radiographic evidence of effaced basal cisterns or at least $1 \mathrm{~cm}$ of midline shift on neuroimaging performed prior to death. Thus, our findings indicate that it is overly simplistic to consider the number of donors per million population as an indicator of the "performance" of a healthcare system and comparisons with other international jurisdictions should be approached with due consideration of important nuances. If the intent is to develop a metric of donation performance, one potential future strategy could be to adjust the donation rate by the 
population rate of poor functional outcomes attributable to brain injury.

Our analysis has limitations. Because data collection was retrospective, conclusions are based on adequacy of documentation in the medical records. Just because there was sometimes no documentation, it does not necessarily follow that there was no consideration of donation or appropriate conversations with families. Even when potential DCD donors die within two hours of withdrawal of life-sustaining therapy, it does not necessarily mean that organs can be transplanted, since there are sometimes other reasons why organs are refused (e.g., organ-specific time interval from withdrawal of lifesustaining treatments to death is too long; prolonged hypoxemia or hypotension is present prior to death even if it occurs within two hours; or intraoperative findings are present that preclude procurement). ${ }^{35} \mathrm{We}$ considered neonates and patients with hepatitis $\mathrm{C}$ to be potential organ donors, even though it is usually difficult to find suitable recipients for their organs. Therefore, even with detailed chart review, our study still overestimates DCD potential. Indeed, the highest rates of controlled DCD in the world are in the range of ten donors per million population. ${ }^{36}$ Finally, we did not assess donation potential in the context of medical assistance in dying. A previous report from Belgium found that approximately $10 \%$ of patients dying in this fashion could have been eligible for organ donation. ${ }^{37}$

\section{Conclusions}

Factors influencing organ donation rates in Canada are complex. The greatest potential to increase deceased donation in our region is with more consistent and widespread availability of DCD and higher consent rates. Further research is required to better understand reasons for refusal of consent. The vast majority of potential donors die in urban critical care units, but a disproportionately large number of missed donation opportunities occur in emergency departments and outside of urban centres. Hypoxemic-ischemic encephalopathy following cardiac arrest is by far the most common cause of death in potential organ donors. Findings of regular death audits are important in understanding opportunities for quality improvement.

Funding source This quality improvement initiative was supported by a Grant from Alberta Health

Competing interests Dr. Kramer is the Medical Director of the Southern Alberta Organ \& Tissue Donation Agency. Dr. Kutsogiannis is the former Medical Director of the Human Organ Procurement \& Exchange Program. Ms. Armstrong, Ms. Grantham, and Ms. Kashuba have all worked for the Alberta Organ \& Tissue Donation Agency. Ms. Hornby has worked for Trillium Gift of Life Network and Canadian Blood Services

Author contributions Andreas $H$. Kramer and Demetrios $J$. Kutsogiannis contributed to all aspects of this manuscript, including study conception and design; acquisition, analysis, and interpretation of data; and drafting or revision of the article. Karen Hornby, Denise Armstrong, Sherri Kashuba, and Laura Grantham contributed to study conception and design, data acquisition, and drafting or revision of the article. Christopher J. Doig and Philippe L. Couillard contributed to acquisition, analysis, and interpretation of data, and drafting or revision of the article.

Editorial responsibility This submission was handled by Dr. Sangeeta Mehta, Associate Editor, Canadian Journal of Anesthesia.

\section{References}

1. Rabbat CG, Thorpe KE, Russell JD, Churchill DN. Comparison of mortality risk for dialysis patients and cadaveric first renal transplant recipients in Ontario. Canada. J Am Soc Nephrol 2000; 11: $917-22$

2. Hong Z, Wu J, Smart G, et al. Survival analysis of liver transplant patients in Canada 1997-2002. Transplant Proc 2006; 38: 2951-6.

3. Barnieh L, Manns BJ, Klarenbach DS, McLaughlin K, Yilmaz S, Hemmelgarn $B R$. A description of the costs of living and standard criteria deceased donor kidney transplantation. Am J Transplant 2011; 11: 478-88

4. Karam VH, Gasquet I, Delvart V, et al. Quality of life in adult survivors beyond 10 years after liver, kidney, and heart transplantation. Transplantation 2003; 76: 1699-704.

5. Santana MJ, Feeny D, Jackson $K$, Weinkauf $J$, Lien $D$. Improvement in health-related quality of life after lung transplantation. Can Respir J 2009; 16: 153-8.

6. Dayton JD, Kanter KR, Vincent $R N$, Mahle WT. Costeffectiveness of pediatric heart transplantation. J Heart Lung Transplant 2006; 25: 409-15.

7. Vasiliadis HM, Collet JP, Penrod JR, Ferraro P, Poirier C. A cost-effectiveness and cost-utility study of lung transplantation. J Heart Lung Transplant 2005; 24: 1275-83.

8. Sagmeister M, Mullhaupt B, Kadry Z, Kullak-Ublick GA, Clavien $P A$, Renner EL. Cost-effectiveness of cadaveric and living-donor liver transplantation. Transplantation 2002; 73: 616-22.

9. Canada's Organ and Tissue Donation and Transplantation Communities; Canadian Blood Services. Call to Action. A strategic plan to improve organ and tissue donation and transplantation performance for Canadians. Available from URL: https://blood.ca/sites/default/files/otdt-indx-final-c2a.pdf (accessed May 2019).

10. Canadian Blood Services. Organ Donation and Transplantation in Canada. System Progress Report 2006-2015. Available from URL: https://blood.ca/sites/default/files/ODT_Report.pdf (accessed May 2019).

11. Matesanz R, Dominguez-Gil B, Coll E, Mahillo B, Marazuela R. How Spain reached 40 deceased organ donors per million population. Am J Transplant 2017; 17: 1447-54.

12. Baker A, Beed S, Fenwick J, et al. Number of deaths by neurological criteria, and organ and tissue donation rates at three critical care centers in Canada. Can J Anesth 2006; 53: 722-6. 
13. Barnieh L, Baxter D, Boiteau P, Manns B, Doig $C$. Benchmarking performance in organ donation programs: dependence on demographics and mortality rates. Can J Anesth 2006; 53: 727-31.

14. Canadian Institute for Health Information. Head Injuries in Canada: a Decade of Change (1994-1995 to 2003-2004) - August 2016. Available from URL: https://secure.cihi.ca/free_products/ ntr_head_injuries_2006_e.pdf (accessed May 2019).

15. Kramer AH, Zygun DA, Doig CJ, Zuege DJ. Incidence of neurologic death among patients with brain injury: a cohort study in a Canadian health region. CMAJ 2013; 185: E838-45.

16. Kramer AH, Baht $R$, Doig CJ. Time trends in organ donation after neurologic determination of death: a cohort study. CMAJ Open 2017; 5: E19-27.

17. Canadian Institute for Health Information. Deceased Organ Donor Potential in Canada. Available from URL: https://www. cihi.ca/sites/default/files/organdonorpotential_2014_en_0.pdf (accessed May 2019).

18. Rose C, Nickerson P, Delmonico F, Randhawa G, Gill J, Gill JS. Estimation of potential deceased organ donors in Canada. Transplantation 2016; 100: 1558-63.

19. Alberta Innovates. Available from URL: https://albertainnovates. $\mathrm{ca} /$ (accessed May 2019).

20. Rao V, Dhanani S, MacLean J, et al. Effect of organ donation after circulatory determination of death on number of organ transplants from donors with neurologic determination of death. CMAJ 2017; 189: E1206-11.

21. Hornby $K$, Shemie SD, Appleby A, et al. Development of a national minimum data set to monitor deceased organ donation performance in Canada. Can J Anesth 2019; 66: 422-31.

22. Shemie SD, Doig $C$, Dickens B, et al. Severe brain injury to neurological determination of death: Canadian forum recommendations. CMAJ 2006; 174: S1-13.

23. Cloutier R, Baran D, Morin JE, et al. Brain death diagnoses and evaluation of the number of potential organ donors in Quebec hospitals. Can J Anesth 2006; 53: 716-21.

24. Ipsos Game Changers. Most Canadians (81\%) Willing to Donate Their Organs in the Case of Their Death. Available from URL: www.ipsos.com/en-ca/most-canadians-81-willing-donate-theirorgans-case-their-death (accessed May 2019).

25. Krmpotic K, Payne C, Isenor C, Dhanani S. Delayed referral results in missed opportunities for organ donation after circulatory death. Crit Care Med 2017; 45: 989-92.

26. Canadian Blood Services. End-of-Life Conversations with Families of Potential Donors: Leading Practices in Offering the Opportunity for Donation - August 2014. Available from URL: https://professionaleducation.blood.ca/sites/msi/files/end-of-life_ aug2014.pdf (accessed May 2019).

27. Shemie SD, Baker AJ, Knoll G, et al. National recommendations for donation after cardiocirculatory death in Canada: donations after cardiocirculatory death in Canada. CMAJ 2006; 175: S1.

28. Dhanani $S$, Hornby L, Ward R, et al. Vital signs after cardiac arrest following withdrawal of life-sustaining therapy: a multicenter prospective observational study. Crit Care Med 2014; 42: 2358-69.

29. Kramer AH, Doig CJ. Premortem heparin administration and location of withdrawal of life-sustaining interventions in DCD: lack of high-quality evidence precludes definitive conclusions. Transplantation 2016; 100: e102-3.

30. Turgeon AF, Lauzier $F$, Simard JF, et al. Mortality associated with withdrawal of life-sustaining therapy for patients with severe traumatic brain injury: a Canadian multicentre cohort study. CMAJ 2011; 183: 1581-8.

31. Kramer AH, Zygun DA. Donation after cardiocirculatory determination of death: we need to respect and protect braininjured patients. Am J Respir Crit Care Med 2014; 189: 504-5.

32. Weiss MJ, Hornby L, Rochwerg B. Canadian guidelines for controlled pediatric donation after circulatory determination of death - summary report. Pediatr Crit Care Med 2017; 18: 103546.

33. Escudero D, Otero J, Menendez de Leon B, Perez-Basterrechea $M$. Organ donation and elective ventilation: a necessary strategy. Biomed Res Int 2017; DOI: https://doi.org/10.1155/2017/ 7518375.

34. Monette $M$. The ever-muddled Canadian waters and elective ventilation. CMAJ 2012; 184: E839-40.

35. Kutsogiannis DJ, Asthana $S$, Townsend DR, Singh G, Karvellas $C J$. The incidence of potential missed organ donors in intensive care units and emergency rooms: a retrospective cohort. Intensive Care Med 2013; 39: 1452-9.

36. Canadian Blood Services. Organ Donation and Transplantation in Canada. System Progress Report - 2017 Update. Available from URL: $\quad$ https://blood.ca/sites/default/files/System_Progress_ Report_2017_Update_FINAL-EN.pdf. (accessed May 2019).

37. Bollen J, van Smaalen T, ten Hoopen R, van Heurn E, Ysebaert $D$, van Mook $W$. Potential number of organ donors after euthanasia in Belgium. JAMA 2017; 317: 1476-7.

Publisher's Note Springer Nature remains neutral with regard to jurisdictional claims in published maps and institutional affiliations. 